Arkadiusz Morawiec*

\title{
Polish literature and the Konzentrationslager. The beginning
}

\section{Introduction}

It would be difficult to identify the first publication in the global literature regarding the Nazi German concentration camps. If one considers the term literature as extensively as in the case of the focus of literary theory studies as Stefania Skwarczyńska did when she considered it as all meaningful verbal creations ${ }^{1}$, one should consider as such any document based on which the institution of Konzentrationslager, the concentration camp, was established. Such a consideration of the term literature does prove useful, as well as convenient, only in reference to the beginnings (let me use the less controversial, less defined term than literature) of writings regarding the camps. The above-mentioned document is, of course, the focus of mainly historians, while for a literary scientist it is the terminus a quo of camp literature (or, more precisely, lager literature, i.e. regarding Nazi camps $)^{2}$, generally considered (also by me) as a type of writings with a dominant aesthetic function or one where that function plays an important role. In short, it would apply to fiction and that variety of writings which are defined as fringe literature, quasi-literature, and personal document literature. It is a quite common formal (genological) manner of defining the area of camp literature (constituting a thematic variety of writings). However, one cannot omit neighbouring non-literary sources when seeking the sources of lager literature.

The line dividing the area of camp literature studied by literary scientists and the area of writings regarding the camps and studied by historians is not always clear. In many cases it is fairly blurred. One example of that is Dymy nad Birkenau by Seweryna Szmaglewska, labelled by Kazimierz Wyka a "fringe novel" 3 and

\footnotetext{
* Prof. of the University of Lodz, Chair of Polish Literature of the 20th and 21st Century, Faculty of Philology, University of Lodz; e-mail: arkadiuszmorawiec@poczta.fm

${ }^{1}$ S. Skwarczyńska, Wstęp do nauki o literaturze, vol. 1, Pax, Warsaw 1954, pp. 72-73. This radically expanded concept of literature included correspondence, and journalistic coverage.

${ }^{2}$ I did not include in the discussion Gulag literature, i.e. literature regarding Soviet concentration camps. It does, of course, constitute an extensive and significant area of camp literature.

${ }^{3}$ K. Wyka, "Pogranicze powieści," Twórczość, vol. 2, 1946, pp. 145-150.
} 
the opinion of Krzysztof Dunin-Wąsowicz, a historian, on the issue of corruption amongst the SS at Auschwitz stating: "It was convincingly described by Tadeusz Borowski in his Oświęcim stories, which were full of extraordinary realism and which were rather a memoir than a literary description." "4

No journey to the sources of Polish lager literature could be complete without foreign-language sources either.

\section{The institution of the concentration camp}

The founding document in question, which indirectly resulted in the birth of lager literature, was a resolution of 28 February 1933 on "the protection of the nation and the state" passed by the German government and announced by the president as a resolution with immediate effect. The resolution constituted the basis for establishing the institution of protective custody (Schutzhaft), fulfilling the function not only de iure preventive, but also educational (supposedly training for "honest work") but, as it soon turned out, mainly repressive and exterminational ${ }^{5}$. From the very beginning, "protective custody" was a means of police enforcement, remaining de facto outside of any control of general judicial

${ }^{4}$ K. Dunin-Wąsowicz, Ruch oporu w hitlerowskich obozach koncentracyjnych 1933-1945. 2nd edition, Warsaw 1983, Państwowe Wydawnictwo Naukowe, p. 188. Initially, when there were still no academic studies, the main sources of knowledge on the camps were the records by people who managed to escape. Even though, in time, there began to appear academic discussions (a dichotomy emerged: subjective memoirs, literature vs. objective, academic studies), it is symptomatic that many of them, or even a majority of them in Polish writings, were authored by former internees. Apart from Dunin-Wąsowicz I can refer to Tadeusz Cieślak (a monograph on the Sachsenhausen camp), Stanisław Dobosiewicz (Mauthausen-Gusen), Wanda Kiedrzyńska (Ravensbrück), Teodor Musioł (Dachau), and Mieczysław Mołdawa (Gross-Rosen). Those authors usually included into the collected material their own experiences to, as one of them put it, "recreate and preserve a more complete description of life in the camp" (T. Cieślak, Oranienburg-Sachsenhausen. Hitlerowskie obozy koncentracyjne 1933-1945, Książka i Wiedza, Warsaw 1972, p. 9).

${ }^{5}$ I am referring to the information provided in the following studies: E. Kogon, Der SS-Staat. Das System der deutschen Konzentrationslager. Europäische Verlagsanstalt, Frankfurt am Main 1946, pp. 38-52; Cz. Pilichowski, "Hitlerowskie obozy i ośrodki przymusowego odosobnienia oraz ich rola w realizacji programu ludobójstwa i zagłady narodu polskiego", [in:] Obozy hitlerowskie na ziemiach polskich 1939-1945. Informator encyklopedyczny. Author and editorial team: Cz. Pilichowski et al. Państwowe Wydawnictwo Naukowe, Warsaw 1979, pp. 11-84; H. Kühnrich, Der KZ-Staat. Die faschistischen Konzentrationslager 1939 bis 1945. Dietz, Berlin 1980; K. Dunin -Wąsowicz, Ruch oporu..., pp. 24-47; F. Ryszka, Państwo stanu wyjątkowego. Rzecz o systemie państwa i prawa Trzeciej Rzeszy. 3rd edition amended, Ossolineum, Wrocław 1985, pp. 353-373; Z. Mańkowski, “Obozy hitlerowskie - Majdanek - Lubelszczyzna”, [in:] Majdanek 1941-1944. T. Mencel (ed.). Wydawnictwo Lubelskie, Lublin 1991, pp. 19-24; W. Sofsky: The Order of Terror. The Concentration Camp. Trans. W. Templer. Princeton University Press, Princeton 1997, pp. 28-43; N. Wachsmann, Historia nazistowskich obozów koncentracyjnych. Trans. M. Antosiewicz, Świat Książki, Warsaw 2016. 
or administrative rule. German citizens, people who were considered "enemies of the state and the nation," particularly communists and social democrats, and pacifists were sent in large numbers, without any court sentences, for an indefinite period of time to confinement centres, which featured the distinct character of the first concentration camps. The decision regarding internment in a camp was formally made by the general administration and the police, but in practice it was issued by the NSDAP party squads (Nationalsozialistische Deutsche Arbeiterpartei): the SA (Sturmabteilungen) and the SS (Schutzstaffeln), which received temporary rights of auxiliary police. Some of the first internment centres were the camps in Quednau, Papenburg-Esterwegen, Lichtenburg, and Sonnenburg. Those and other unofficial camps were established through the initiative of local SA or SS commanders. By 30 April 1933, 30,000 people were interned there. By late 1933 , there were several dozen such camps operating in Germany. The majority of them were small, designed for several hundred or a few thousand inmates at the most. They were often located in adapted former prisons or factory buildings.

The first "legalised" concentration camp began operating on 22 March 1933 in Dachau near Munich. It was established on the basis of a resolution issued by Heinrich Himmler, the appointed president of the police in Munich. The camp, managed from the very beginning by the SS, became a "trial and model" camp. In April 1933, when the Gestapo (Geheimestaatspolizei) was established, Herman Göring, the prime minister and the minister of the interior of Prussia at that time, approved Himmler's initiative accepting the institution of concentration camps as "legal and state-approved", and a uniform management and supervision over the institution of concentration camps was established. Almost at the same time as the Dachau camp, the camp in Oranienburg was established, managed by the SA which initially managed all camps except the Dachau one. When Ernst Röhm and the SA were dealt with by Hitler's forces on 30 June 1934 during the so-called Night of the Long Knives, total control over all camps was seized by the SS. As a consequence, the majority of small camps were closed. Some of the internees were released while the rest were transferred to the larger camps.

In the years 1936-1939, according to the guidelines of the SS command, the tasks of concentration camps included the internment and neutralisation of political opponents of the regime suspected of continuing their activities against the authorities. In that period, the camps received whole groups of communists and social democrats, opposition clergymen, pacifists, Jews and people considered on the basis of the Nuremberg Laws to be Jewish, as well as Jehovah's Witnesses (members of the Bible Student movement), Freemasons, disloyal members of Hitler's organisations, and (after August 1939, though sometimes even before then) Polish community activists in Germany. Gradually, the camps received increasing numbers of so-called asocial individuals, i.e. criminals, vagabonds, prostitutes, homosexuals, and Gypsies. Based on a resolution of the minister of the interior of the Reich of 25 January 1938, internment in a camp was defined as indefinite. 
Any and all further decisions regarding internment were made solely by the SS command. Prior to the outbreak of WWII, there existed an extensive system of concentration camps in Germany. That was a result of the so-called second wave of their development. As a result: in 1936, the camp in Sachsenhausen was created (replacing the camps in Oranienburg and Esterwegen), in the following year, KL Buchenwald was created (replacing the camps in Lichtenburg, Sonnenburg, and Brandenburg), in 1938, the camps in Flossenbürg, Mauthausen (in the annexed Austria), and Neuengamme (initially as an auxiliary camp to the Sachsenhausen camp) were established. In 1939, the women's camp in Ravensbrück was established. The notion of the "concentration camp" (as a place of serving Schutzhaft) applied only to the Buchenwald, Dachau, Flossenbürg, Mauthausen, Sachsenhausen, and Ravensbrück camps. The number of "state camps" was soon to rise.

On 28 August 1939, in relation to the planned aggression against Poland, Reinhard Heydrich, the chief of the Reich Main Security Office, issued a circular ordering the expansion of the tasks of the existing concentration camps: preparations for the elimination of entire social and national groups considered as undesired. Thus, within a short time, once innocent or even pleasant-sounding names such as Beech Forest (Buchenwald) became terrifying, and some places even gained the position of literary characters.

\section{Sources of knowledge on lagers (initial)}

In the initial period of the functioning of Nazi concentration camps, the fact of their existence was public, and often discussed in the Nazi press 6 . The information provided was, of course, only the official statement on what the camps truly were. The more real image of the lager, inaccessible to a wider group of receivers, formed on the basis of personal contacts of the internees with their families, which were initially allowed, though not for everyone, and thanks to their coming into contact with free people, particularly when they were sent to work outside the camps (in the initial period, though, relatively few internees received jobs). Quite quickly those opportunities were limited to a minimum. (New opportunities of coming into contact with civilians were possible as late as 1942-1943 when the internees were sent in their masses to work in the arms industry). Sometimes (more often at the end of WWII), pieces of information from the internees were carried by some camp staff members driven rather by material benefit than compassion or kinship towards the internees (though the latter cases also occurred). Sometimes information from the camps was sent in censored letters to the

${ }^{6}$ I used mainly the facts provided in a monograph by K. Dunin-Wąsowicz, Ruch oporu... (particularly the chapter: Łaczność i przeptyw informacji między obozami a światem zewnętrznym (Communication and information flow between the camps and the outside world), pp. 155-180). 
families inscribed between the lines using invisible ink (urine). An important role in transferring information was played by a contact network of anti-fascist organisations, which was established soon after Hitler's rise to power. It worked quite efficiently in 1933-1934 but it was soon shattered as a result of targeted arrests. (An exceptionally efficient contact network was re-established several years later, during WWII, rather in camps located in lands ethnically Polish than German, particularly in Auschwitz and Majdanek, utilising the local population, and civilian labourers). In all the above-mentioned instances, the contacts between the internees and the outside world were usually based on oral accounts or illicit kites. A particular source of (official) information were the numerous reports sent out by the camp command on the deaths of internees - young people who had still been healthy a short time before.

Without a doubt, the oral accounts of people released from the lagers constituted a richer, more comprehensive sources of knowledge. They were usually intended for a small group of people, mainly family and friends. Before being released, the internees signed a letter of obligation that they would keep secret everything they had seen and experienced in the lager. Violation of the obligation was punishable with re-internment. It should be stated that in 1933-1939, the number of releases from the camps was considerable. The main source of information which shaped the image of the lager in global opinion were the published accounts by those who were released from the camps, and the few escapees.

\section{Publications}

Publications regarding concentration camps were released both in the Third Reich as well as abroad. To ensure the safety of their authors, they included mainly the accounts of emigrants. According to Dunin-Wąsowicz's calculations, in the years 1933-1939, a total of 42 books and printed brochures were published and a number of copied publications, while some had several editions in different languages. From among those 42 books and brochures ${ }^{7}, 10$ were published in France and Switzerland respectively, 5 in the United Kingdom, 4 in the Netherlands, 3 in Czechoslovakia and Poland respectively, and 1 in Japanese-occupied Shanghai. It was symptomatic that as many as 6 books were published in the Soviet Union, the world's first camp runner-up. The majority of the publications appeared in 1933-1934. A rise in the interest in the world of Nazi camps began in 1939.

${ }^{7}$ K. Dunin-Wąsowicz, Ruch oporu..., pp. 160-161. Vide also W. Kiedrzyńska, "Międzynarodowa bibliografia hitlerowskich obozów koncentracyjnych 1933-1976." Biuletyn Głównej Komisji Badania Zbrodni Hitlerowskich, [vol.] 30 (1981), pp. 9-240. The number offered by Dunin-Wąsowicz was an estimate. The author (just like Kiedrzyńska) did not know, e.g. the book by Stanisław Nogaj entitled Za drutami i kratami Trzeciej Rzeszy (I discuss it later in the article). 
In the Third Reich, camp-themed publications were released in the form of copied prints and leaflets, as well as in the form of Tarnschriften, i.e. mass prints inserted between book covers and brochures not arousing suspicion and thus allowed by the censors. For example, the memoir of Gerhart Seger, an escapee from Oranienburg, was published under a cover which bore the title Das Gesetz zur Ordnung der Nationalen Arbeit, the memoir of Werner Hirsch entitled Sozialdemokratische und kommunistische Arbeiter im Konzentrationslager was included in the print publication by Wilhelm Meyer and Karl Wernicke entitled Der Elektromotor im Kleingewerbe und Haushalt, whereas the account by Kurt Hiller, entitled Erich Mühsams Tod, regarding a poet killed in Oranienburg, was published in a book entitled Deutsch für Deutsche ${ }^{8}$. Many brochures and articles were devoted to Mühsam, and similarly to Carl von Ossietzky, a journalist and writer, a pacifist, interned first in the Sonnenburg camp, later transferred to Esterwegen, and eventually released as a result of his winning the Nobel Peace Prize in 1935.

Information on the camps was also published in the German press, both underground and emigrant-based. A considerable number of publications appeared in the English and French press ${ }^{9}$. Another source of knowledge on the lagers were journalists who were sometimes, similarly to the representatives of the Red Cross, allowed inside the camps (I shall return to this further in the article).

One of the first publications which included information on the crimes committed by the Nazi regime was an extensive reference study entitled Braunbuch über Reichstagbrand und Hitler Terror ${ }^{10}$, which included a chapter on the "model camps" in Heuberg, Oranienburg and Dachau, and the "torture chambers" in Sonnenburg and in the Königstein castle. It was authored by emigrants who also used documents acquired by Hitler's opponents operating in the Reich. In response to the publication and Seger's memoir entitled Oranienburg from 1934 (vide further) and his lectures and articles published abroad, the regime, still taking into account international opinion, ordered through Goebbels, the minister of propaganda, SA-Sturmbannführer Werner Schäfer to write an anti-brown book entitled Konzentrationslager Oranienburg ${ }^{11}$.

However, as I have already mentioned, the main role in shaping global public opinion on the issue of what Nazi concentration camps were was played by

${ }^{8}$ Das Gesetz zur Ordnung der Nationalen Arbeit. Leipzig [1934], Harmonie (Seger's text on pp. 13-44, 51-80); W. Meyer, K. Wernicke, Der Elektromotor im Kleingewerbe und Haushalt. Hachmeister \& Thal, Leipzig [1934]; Deutsch für Deutsche. Leipzig [1935], A. Otto Paul (Hiller's account on pp. 74-78). Cf. also H. Gittig, Illegale antifaschistische Tarnschriften 1933 bis 1945. VEB Bibliographisches Institut, Leipzig 1972.

${ }^{9}$ Vide K. Dunin-Wąsowicz, Ruch oporu..., pp. 163-164.

${ }^{10}$ Braunbuch über Reichstagbrand und Hitler Terror, Basel 1933, Universum. Underneath the introduction, there is a date: August 1933.

${ }^{11}$ W. Schäfer, Konzentrationslager Oranienburg. Das Anti-Braunbuch über das erste deutsche Konzentrationslager. Buch- und Tiefdruck-Gesellschaft, Berlin [1934]. 
the publications of emigrants: both escapees from lagers, particularly by Hans Beimler, Seger, and Heinz Liepmann, as well as people released from camps, i.a. Wolfgang Langhoff, Kurt Hiller, Werner Hirsch, Willy Bredel, and Julius Zerfaß. Those publications included both memoirs and strictly literary texts.

The escape of Beimler, a communist deputy to the Reichstag, from Dachau was probably the first, and certainly one of the most famous, escapes during the initial period of camp operations. Beimler escaped at night on 9 May 1933, he fled to Switzerland and wrote down his experiences soon afterwards. His account was published in Moscow by the end of that year ${ }^{12}$. It was one of the first publications of that type. It was soon translated into several languages and it made a huge impression around the world ${ }^{13}$. A similarly famous escape was that of Seger, a social democratic deputy to the Reichstag, from the concentration camp in Oranienburg on 4 December 1933. The next day, he managed to pass into Czechoslovakia where he quickly wrote down his memoir. It was published, with a preface by Heinrich Mann, by a social democratic émigré publishing house ${ }^{14}$. Soon afterwards, new accounts began to appear, both collective and individual ${ }^{15}$, written not only by Germans ${ }^{16}$.

Literary texts, not excluding German ones and those not always written by people who knew the camps from their own experience, played a significant role in propagating knowledge on the camps. The most important examples of those

\footnotetext{
${ }^{12}$ H. Beimler, Im Mörderlager Dachau. 4 Wochen in den Händen der Braunen Banditen. Ausländischer Arbeiter in der UdSSR, Moskau 1933.

${ }^{13}$ Vide S. Dymek, Hans Beimler (1895-1936). Ministerstwo Obrony Narodowej, Warsaw 1975, pp. 24-25.

${ }^{14}$ G. Seger, Oranienburg. Erster autentischer Bericht eines aus dem Konzentrationslager Geflüchteten. Afterword by Heinrich Mann. Karlsbad 1934, Graphia. Polish review of the book: “O czym p. Goebbels nie mówił w Warszawie? Obóz izolacyjny - Oranienburg”. Robotnik, 1934, issue 221 , p. 3.

${ }^{15}$ Vide, e.g.: Mord im Lager Hohenstein. Berichte aus dem Dritten Reich. Ausländischer Arbeiter in der UdSSR, Moskau 1933; M. Abraham, Juda verrecke. Ein Rabbiner im Konzentrationslager. Introduction K.L. Reiner. Teplitz-Schönau 1934, [publishing house missing]; Aus Hitlers Konzentrationslagern. Kurt Bürger (ed.). Ausländischer Arbeiter in der UdSSR, Moskau 1934; Escaped Prisoner [uncredited], The Sonnenburg Torture Camp. Workers Library Publishers, New York 1934; W. Hirsch, Hinter Stacheldraht und Glitter. Erlebnisse und Erfahrungen in den Konzentrationslagern und Gefängnissen Hitlerdeutschlands. Zürich-Paris 1934, Mopr; ibid.: Sozialdemokratische and kommunistische Arbeiter im Konzentrationslager. Prometheus, [Strasbourg] 1934; Als sozialdemokratischer Arbeiter im Konzentrationslager Papenburg. Introduction Willi Bredel. Ausländischer Arbeiter in der UdSSR, Moskau 1935; W. Langhoff, Die Moorsoldaten. 13 Monate Konzentrationslager. Unpolitischer Tatsachenbericht. Schweizer Spiegel, Zürich 1935; K. Hinrichs, Staatliches Konzentrationslager VII. Eine „Erziehungsanstalt” im Dritten Reich. Malik, London 1936. Walter Hornung [aka Julius Zerfaß]; Dachau - Eine Chronik. Europa, Zürich 1936; M. Siegelberg: Schutzhaftjude 13877. Die Leidensgeschichte zweier Menschen. Sygma, Shanghai 1939.

${ }^{16}$ N. Rost, De brouwerij van Oraniënburg. Een concentratiecamp in het Derde Rijk. Amsterdam 1933, [publishing house missing]; R. B. Gul, Oranienburg. Čto ja videl v gitlerovskom koncentracionnom lagere. Dom Knigi, [Paris 1937].
} 
included a novel by Bruno Frank, who emigrated in 1933, entitled Der Reisepass $^{17}$, in which the theme of the concentration camp appeared in the background; a documentary novel by Paul W. Massing, a communist interned in Oranienburg, entitled Schutzhäftling $880^{18}$; "a documentary novel on contemporary Germany" entitled Das Vaterland by Heinz Liepmann ${ }^{19}$; but most of all Die Prüfung (Examination) by Willi Bredel, a communist internee of the Hamburg-Fuhlsbüttel camp. The story of Liepmann's work, an author of Jewish ancestry persecuted by the regime, was located in Hamburg and partly, on a dozen or so pages, in Wittmoor concentration camp, which he knew from his own experience and from which he had managed to escape. Das Vaterland, a work dedicated to Jews murdered in Nazi Germany, which presented the overwhelming terror, was the first novel on Nazism. It was published in Amsterdam, and translated into 17 languages, but resulted in Liepmann's being tried in the Netherlands for "offending the leader of a friendly state", a month-long imprisonment, and his eventual expulsion to Belgium ${ }^{20}$. Bredel's book was the first lager-themed novel, and has become one of the most famous items (not only among pre-WWII publications) of global camp literature. It was published in the autumn of 1934 in London ${ }^{21}$.

In the introduction to the first German edition of his novel of 1946, Bredel stated that it came to his mind "during the weeks and months of his solitary confinement in the concentration camp", which is why writing it down in Prague, to where the author travelled after being released from the camp, was merely a technical issue ${ }^{22}$. He also emphasised, as he had already in the London edition, the documentary character of the book: the facts he presented were known to him from his own experience, only some of them had he learnt from fellow internees he trusted. He assured readers that the novel did not include any made up characters. The names of the SS officers were real, only the names of the internees were changed to ensure their safety, as well as some details of their experiences. The writer dedicated the German edition to "Mathias Thesen, the brave son [...] of his nation, martyr in the fight for freedom and humanity" (p. 6). Thesen, a communist deputy to the Reichstag, was also the prototype of the main protagonist of the novel, the "steadfast fearless communist" Heinrich Torsten (p. 6). The documentary

${ }^{17}$ B. Frank, Der Reisepass. Roman. Querido, Amsterdam 1937.

${ }^{18}$ K. Billinger [aka P. W. Massing], Schutzhäftling 880. Aus einem deutschen Konzentrationslager. Roman. Carrefour, Paris 1935.

${ }^{19}$ H. Liepmann, Das Vaterland. Ein tatsachen Roman aus dem heutigen Deutschland. P.N. van Kampen \& Zoon N. V., Amsterdam 1933.

${ }^{20}$ Vide W. Kunicki, "Liepmann Heinz”, [in:] Pisarze niemieckojęzyczni XX wieku. Leksykon encyklopedyczny PWN. Marek Zubyra (ed.). PWN, Warsaw 1996, p. 202.

${ }^{21}$ W. Bredel, Die Prüfung. Roman aus einem Konzentrationslager. Malik. London 1934. 1st edition in Germany: Aufbau, Berlin 1946.

${ }^{22}$ W. Bredel: Egzamin. Powieść. Trans. Anna Linke. Państwowy Instytut Wydawniczy, Warsaw 1954, p. 5 (hereinafter, I state the locations of the quotes directly after the quotes). 
character of the novel was confirmed by the author's reference in the afterword to the fact that 15 years later it was used "as a «report» by the jury during the Nuremberg Trials" as evidence in the trial against the commander and the guards of the Hamburg-based Fuhlsbüttel concentration camp (p. 325).

Equipped with the factographic milieu, Bredel's book did in fact prove to be a novel. The autobiographical experiences, clearly significant for the novel's creation, were unclear and invisible for a reader unfamiliar with the writer's biography. The author consistently used narration in the third person and the narrator is omniscient. The source which proved just as important as the author's experiences and the accounts of his fellow internees was his imagination. Fictionalisation was applied to citations (dialogues), the narrator investigated the thoughts and dreams of not only the main protagonist, but also Gottfried Miesicki, a Jewish merchant, and even the SS officers; he also told the dream of Kreibel, the communist. The novel also included scenes where the only "actors" were the camp guards (in the introduction, Bredel did not mention any reliable guards at all). Examination was, thus, a typical realistic novel not different in terms of its form from completely fictional novels. Let me put this more precisely: it was a thesis novel. Therefore, documenting facts was not the only important issue for the author. He placed a similarly strong emphasis on the ideological influence of the book, shaping it in such a way as to ensure the favourable disposition among the readers not even for anti-fascist opposition activists, but mainly for communists.

The story unfolds within the period from the summer of 1933 to the spring of 1934 in Hamburg. Torsten, the main protagonist, had come to the city from Chemnitz where "the heat was coming on to him." (p. 7) His task was to form new ranks due to the arrests of three hundred of the best Hamburg activists. But he was arrested on the day he came to the city. While being detained, in severe conditions, Torsten noticed lucidly: "even in prison or in a concentration camp, there is a lot to do" (p. 47); "in prison, the objective is to inspire the masses through one's example of the highest ethics and to disrupt the enemy's operations" (p. 48). Despite being tortured, Torsten not only did not give up any of his comrades, but even, once placed in the Fuhlsbüttel camp, decided to enlighten politically the camp doctor, a member of the SA, a decent man, who was drawn to Hitler because of "emotional and economic" reasons (p. 200). He decided to help him.

However, Torsten's (and Bredel's) opponents were not only their torturers, the Nazis. One of the more extensively presented characters was the interned and cruelly tormented Doctor Fritz Koltwitz, a "decent social democrat" (p. 6). The character was based on, as Bredel stated in the introduction, Doctor Solmitz from Lübeck. Tortured to the extreme, approached with compassion by the narrator, Koltwitz eventually wanted to survive only "for his wife and children. Only for them, never again for the comrades" (p. 86). His torturers drove him to committing suicide. At the same time, Torsten the communist did not cave in, even in his mind he did not abandon his comrades. The superiority of the communist stance over 
the social democratic was eventually confirmed by Schneeman, another internee and a social democrat, accepting the principles of the communists held in the same cell as he was. Further on in the novel, the author removed Torsten relocating him from the camp to an investigation prison. The main role was transferred onto the group of communist internees who conducted talks and discussions on political issues for personal improvement. Soon one of the main characters became Walter Kreibel, who was released from the camp. Or rather not he himself but the dilemma that fermented in him: should he completely distance himself from his former comrades and focus on family life or return to political life. Eventually, Kreibel, regardless of the threat of re-internment and a menacing dream in which he saw the death of Fritz Janke, a communist, who was beheaded by the Nazis in a bathtub (which is an allusion to the death of Jean-Paul Marat), accepted the offer to engage in "work" in Frankfurt. The final part of the novel presented the fruit of the steadfast Torsten. Kreibel's remaining doubts: "not all communists are like Heinrich Torsten. Not all of them carry in their hearts so much love to the party. Not all of them believe so strongly in the victory of the working class. Not all of them are so tough, so generous..." (p. 314), were eventually dispelled by one of the comrades who states emphatically: "The party has many Torstens" (p. 319).

The global appeal of pre-WWII camp literature was a result of not only the accounts of two writers: a Dutchman Nik Rost and a Russian Roman B. Gul'23, but also, or most of all, the story by a French writer André Malraux published in 1935, entitled Le temps de mépris (Days of Wrath) ${ }^{24}$. Malraux was the first widely known and acclaimed writer who introduced in a work of literature the theme of German concentration camps. The author's knowledge on lagers was based on the accounts of other people, which was emphasised in the dedication: "TO GERMAN COMRADES, who decided to pass over to me what they suffered through and what they retained, THIS BOOK WHICH IS THEIR BOOK" ${ }^{25}$. The story mainly presented the time Kassner, the main protagonist, a German communist and writer, spent in a lager. It presented his experiences. The camp was only outlined, limited to the darkened place in which Kassner was kept. The personal narration, which combined a realistic view with a view filtered through a mind shattered by the tortures inflicted by the SS officers and hunger (the story included the term "controlled insanity"), contrasted the current experiences of the protagonist with his earlier recollections: a visit to the Soviet Union and the fight, hand in hand with Bolsheviks, in the civil war, his activities in the international workers' movement, and family life. The composition of Malraux's character is much more complex and artistically more effective than that in Bredel's novel. The French writer, who in the 1930s was fascinated with Marxism, gave his communist protagonist attributes necessary for

\footnotetext{
${ }^{23}$ N. Rost, De brouwerij van Oraniënburg...; R. B. Gul, Oranienburg...

${ }^{24}$ A. Malraux, Le temps de mépris. Gallimard, Paris [1935].

${ }^{25}$ A. Malraux, Czasy pogardy. Trans. Wacław Rogowicz. Rój, Warsaw 1936, p. 25.
} 
an existential (in its non-religious version) approach to man. Malraux did mark his aversion towards exuberant individualism, but he did not submit his character completely to "the cause". Kassner was not, unlike Torsten, a monument, a monolith. He was mainly interested in the problem of solitude and death, and making death advantageous (a mere coincidence (the unexpected release from the camp) seemed to have saved Kassner from committing suicide). Eventually, the sense of dignity proved a remedy for suffering, while brotherhood and sacrificing oneself for the Other an existential guidepost. The story discreetly introduced the theme of Prometheus, however, it was not the abstract collective nor socio-economic relations that constituted the social existence that determined the protagonist's consciousness, but an individual (the Other). In the introduction, Malraux stated that the aim of art should be to strive to make people aware of their own grandeur which remains unknown to them. That optimistic proposition was complemented in the story by the idealised vision, confronted with the reality of a Nazi lager, of Soviet reality: a society where there is no one who would know the time of contempt ${ }^{26}$. The same applied to Bredel's novel. One of the communist internees told his comrades, hungering for knowledge, about his stay in the Soviet Union, naturally in a tone full of admiration.

Let us return to the preface opening Examination. It indicated that Bredel's novel was created in the camp, more precisely: in the camp, the author developed the idea, presumably even its plan. Hence, what is noteworthy, there is not only "the camp in literature" (as a theme), but also "literature in the camp". The latter phenomenon should be considered twofold: first of all, people read literature in the camps, they listened to it (recited, sang, told), even literary competitions were organised and theatre plays were staged; secondly, literature was created in the camps, not exclusively camp-themed ${ }^{27}$. The literature written in the camps was rather prolific, especially in the field of poetry. During the pre-WWII period of the existence of the camps, the internees wrote almost always in German. That was a result of the composition of the internees. I was unable to identify any texts in Polish ${ }^{28}$, although they proliferated during WWII. I will only add that one of

\footnotetext{
${ }^{26}$ It is worth mentioning that in 1934 Malraux participated in a congress of Soviet writers in Moscow.

${ }^{27}$ More on the subject, vide A. Morawiec, Literatura w lagrze, lager w literaturze. Wydawnictwo Akademii Humanistyczno-Ekonomicznej w Lodzi, Łódź 2009.

${ }^{28}$ In the light of the studies on specific camps: Poles were sent to Sachsenhausen before the outbreak of WWII only in exceptional cases, and they were not even registered as Poles (vide T. Cieślak, Oranienburg-Sachsenhausen..., p. 83), in Dachau, the first Poles were interned on 16 September 1939 (T. Musioł, Dachau 1933-1945. 2nd edition, amended. Instytut Śląski, Śląsk, Opole-Katowice 1971, p. 90), in Ravensbrück, the first Polish women were interned on 23 September 1939 (vide W. Kiedrzyńska, Ravensbrück. Kobiecy obóz koncentracyjny. 2nd edition, amended. Książka i Wiedza, Warsaw 1965, p. 59). Przemysław Mnichowski claimed that the first Pole in Sonnenburg was interned on 28 November 1939 (ibid.: Obóz koncentracyjny i więzienie w Sonnenburgu (Stońsku) 1933-1945. Ministerstwo Obrony Narodowej, Warsaw 1982, p. 57), yet Stanisław Nogaj already
} 
the first and probably the most popular songs created in the camps, translated (already in the camps) into many languages, including Polish, was Moorsoldatenlied, a song created in the Börgermoor camp near Papenburg, performed there on 27 August 1933, completing a show prepared by the internees entitled Zirkus Konzentrazani. It was based on a poem by Johann Esser, a miner, with an added chorus by Wolfgang Langhoff. The song "escaped" the lager and was published on 8 March 1935 in a Prague-based émigré communist daily Arbeiter Illustrierte Zeitung. Therefore, literary texts created in the camps were, however seldom, a source of knowledge on them. Songs similar to Moorsoldatenlied (camp hymns) were created in other camps as well29. For example, in Buchenwald in 1938, Fritz Löhner-Beda, a well-known libretto writer, wrote Buchenwaldlied - sang by many internees with the consent or even at the order of the SS officers. In that and other camps, Löhner-Beda composed other poetic works, e.g. Buna-Lied in Auschwitz III (i.e. in Monowitz).

Dunin-Wąsowicz presumed that the writings regarding the camps reached few German readers within the Reich ${ }^{30}$. At the same time he emphasised that they were quite popular in western states, though not amongst the general public, rather the intellectual elites and leftist communities ${ }^{31}$. It must be stated that there also existed a demand for such writings in Poland, which was as much a result of curiosity and concern for what was happening in the neighbouring country as, I believe, an interest in the exoticism of the world presented in them.

\section{Publications in Poland and in Polish}

In the opinions of critics and historians of Polish literature, one can find claims or at least suggestions that Seweryna Szmaglewska was the first to undertake to describe the reality of a German concentration camp or that her Dymy nad Birkenau,

in 1937 listed Sonnenburg as one of the two main camps, apart from Lichtenburg, to which Poles were sent (ibid.: Za kratami i drutami Trzeciej Rzeszy (Reportaże). [Polonia], [Katowice] 1937, p. 50). Incidentally, some Poles interned in camps before WWII found out to their astonishment that they were... German citizens (cf. ibid., p. 85). There is no doubt, though, that the majority of Poles interned at that time were, in fact, citizens of Germany. Thus, the "adjustment" regarding Dachau: the first Polish citizens of Germany were interned there in 1935 (vide Autobiografia Rudolfa Hössa, komendanta obozu oświęcimskiego Trans. W. Grzymski. Foreword F. Ryszka. Notes developed by A. Pankowicz. Wydawnictwo Prawnicze, Warsaw 1990, p. 62, note 13).

${ }^{29}$ Vide Z. Kachnicz, "Muzyka, pieśni i piosenki jako sposób na samoobronę psychiczną więźniów obozów hitlerowskich.” Przegląd Humanistyczny, 2005, issue 2, pp. 74-76.

${ }^{30} \mathrm{~T}$. Cieślak was of a different opinion. He claimed that the fact of the writings reaching many inhabitants of the Reich was the publication of the anti-brown book by Schäfer. He stressed that the issue of the camps was well-known to the German general public also through various notes on the camps published in the Nazi press, always supplemented, of course, with appropriate interpretation (ibid.: Oranienburg-Sachsenhausen..., pp. 7-8).

${ }^{31}$ K. Dunin-Wąsowicz, Ruch oporu..., pp. 161-163. 
published in 1945, was the first literary account published after WWII (more precisely: after the capitulation of Germany) on the concentration/death camps, the Auschwitz camp in particular ${ }^{32}$. In fact the book was neither the first report on Auschwitz or any other camp published after the liberation of the Polish lands from the Nazi occupation nor, as the presented discussion proves, the first account on a German concentration camp. I will go even further and state that it was not even the first account from a concentration/death camp in Polish or the first that was published in Poland. I shall omit the numerous publications in Polish published during WWII and right after it in $1945^{33}$. I shall focus solely on the pre-WWII publications regarding German concentration camps printed in Poland (in Polish and in foreign languages, original texts and translations) and abroad (texts in Polish).

Literary historians have overlooked that prehistory of Polish camp literature. Its size is not great, but one should take note of its existence and of the presence in pre-WWII Poland of foreign writings regarding the issue of German concentration camps. I shall begin with translations.

The group of several translations of the previously mentioned Beimler's account from Dachau, included one which was published in Warsaw in Yiddish, and another in Moscow and in Polish, both in $1934^{34}$. In the same year, a Polish translation of the well-known, and earlier-discussed, Brunatna ksiega was published in Warsaw. The Polish translator corrected the originally stated number of the interned of 45,000 adding in brackets: "The latest calculations estimate the number at $100,000 " 35$. In 1938, a translation of a book by Franz Zürcher entitled Krucjata przeciw chrześcijaństwu was published outside of Poland. It documented the persecution of Jehovah's Witnesses in the camps ${ }^{36}$. One should also mention the

${ }^{32}$ Vide, e.g. H. Vogler, "Liryka i piekło.” Dziennik Polski, 1946, issue 69, p. 7; [author uncredited], "Oświęcimskie książki”. Wolni Ludzie, 1947, issue 5, p. 3; A. Z. Makowiecki, "Opowieść o zagładzie: Seweryny Szmaglewskiej «Dymy nad Birkenau».” Kultura, 1969, issue 26, p. 3. I am also including the opinion of Ludwik Rajewski ("Seweryna Szmaglewska". Na straży, 1963, issue 23, p. 11), a former Auschwitz internee, author of studies on lager literature: "It was the first account on the Nazi death camp in Auschwitz", and the statement of D. Kulesza, "Lager prose appeared in the country almost directly after the end of WWII. Seweryna Szmaglewska published her Dymy nad Birkenau (1945), Zofia Kossak entitled her camp memoir $Z$ otchłani (1946). Jerzy Andrzejewski and Wojciech Żukrowski published wartime collections of stories which included lager-themed texts" (ibid.: Dwie prawdy. Zofia Kossak i Tadeusz Borowski wobec obrazu wojny w polskiej prozie lat 1944-1948. Trans Humana, Białystok 2006, p. 213; underline: A.M.). .

${ }^{33}$ Vide A. Morawiec: Literatura w lagrze, lager w literaturze...

${ }^{34} \mathrm{H}$. Beimler, In hitleristishn kontsentracye-lager Dakhau. For vokhn in di hent fun di broyne banditn. Trans. V.L.Z. Varshe 1934, L. Zilberberg; ibid.: W katowni faszystowskich zbirów. Foreword G[ustaw] Rwal. Wydawnictwo Partyjne, Moscow 1934.

${ }^{35}$ Brunatna ksiega. Podpalenie Reichstagu i teror [!] hitlerowski. Foreword Lord Marley. M. Fruchtman, Warsaw 1934, p. 252.

${ }^{36}$ F. Zürcher, Krucjata przeciw chrześcijaństwu. Europa, Zürich-New York 1938, (original edition: Kreuzzug gegen das Christentum. Europa, Zürich-New York 1938). 
translations of works of literature. Soon after the publication of the original, the Polish edition of Liepmann's Das Vaterland entitled Śmierć made in Germany ${ }^{37}$, and a translation of Malraux's Le temps de mépris translated by Wacław Rogowicz (with his introduction) were published ${ }^{38}$. Then in 1938, Bruno Frank's Paszport księcia was published ${ }^{39}$.

Information about the persecution of political opponents in prisons and concentration camps was provided by the Polish press presenting both reprints from foreign-language magazines/journals ${ }^{40}$ and texts by in-house authors. Many publications focussed on Ossietzky's case ${ }^{41}$. In Robotnik, the central organ of the Polish Socialist Party (PPS), the issue of 1 July 1934 included a reprint of an account by an escapee from Sonnenburg, which confirmed the inhumane treatment of a well-known journalist interned there and in Papenburg, where he was later transferred ${ }^{42}$. NB, Robotnik was the first Polish periodical to consistently, in 1934, replace the term "severe prison" with the term "concentration camp". The newspaper offered, as side remarks to Ossietzky's case, the most comprehensive description of the Nazi system of prisons and camps among all Polish periodicals. As Karol Fiedor remarked: "In the first half of the 1930s, Polish readers were still unaware of the methods used by the Nazis against their political opponents, thus, the reports in Robotnik [...] were very important for exposing as well as raising the awareness of the situation." 43 To a large extent, press releases and the resulting reaction of global public opinion helped achieve the eventual release of Ossietzky from the camp. The awarding to

${ }^{37}$ H. Liepmann, Śmierć made in Germany. Powieść. Trans. I[zydor] Berman. Sigma. Earlier, Lwów [1934], Wiadomości Literackie published a translation of the author's introduction to the novel: "Śmierć made in Germany". Wiadomości Literackie, 1934, issue 1, p. 5.

${ }^{38}$ A. Malraux, Czasy pogardy. Trans. W. Rogowicz. Rój, Warsaw 1936. It seems that a trace of the reception of Malraux's novel was a poem by Tadeusz Borowski entitled Czasy pogardy, published in a collection entitled gdziekolwiek ziemia ... cykl poetycki. [Warsaw 1942], col. 5 [without pagination]. Borowski surely read Malraux immediately after WWII (vide Niedyskrecje pocztowe. Korespondencja Tadeusza Borowskiego. Collected, explained, and discussed by Tadeusz Drewnowski. Prószyński i S-ka, Warsaw 2001, p. 170). Andrzej Werner associated the vision included in Borowski's poem of a cruel enslaved world with Stalin's concentration camps (ibid.: "Wstęp", [in:] T. Borowski, Utwory wybrane. A. Werner (ed.), Ossolineum, Wrocław 1991, p. XXXI). I believe that it was so extensive that it encompassed also German camps.

${ }^{39}$ B. Frank, Paszport księcia [Der Reisepass]. Trans. R. Granicy. [Nowa Drukarnia Lwowska, Lviv 1938].

${ }^{40}$ E.g. the translation of an article from the English The New Statesman and Nation (1937, issue 351): Obóz w Dachau. Trans. Zb[gniew] Gr[abowski]. Wiadomości Literackie, 1937, issue 51, p. 7.

${ }^{41}$ Vide K. Fiedor, Militaryzmowi i faszyzmowi - nie. Carl von Ossietzky, życie i walka. Państwowe Wydawnictwo Naukowe, Warsaw 1986, pp. 175-193.

42 “Z praktyki obozów izolacyjnych. Los Karola Ossietzkyego.” Robotnik, 1934, issue 237, p. 1. It was rather meaningful to include underneath the text with a heading Polskie obozy izolacyjne a copy of the first resolution regarding the sending of three people to a (Polish) "isolation camp" (in Bereza Kartuska).

${ }^{43}$ K. Fiedor, Militaryzmowi i faszyzmowi - nie..., p. 183. 
Ossietzky of the Nobel Peace Prize in 1935 also helped that cause and was a result of those operations. Soon afterwards, two brochures in Polish about him were published $^{44}$. It is worth mentioning that the group of Polish writers who spoke out in support of Ossietzky were, e.g. Zofia Nałkowska, Ewa Szelburg-Zarembina, and Jan Nepomucen Miller; they signed a letter of protest addressed to Chancellor Hitler ${ }^{45}$. Antoni Słonimski wrote a column about the interned journalist independently ${ }^{46}$.

A result of the Nazis' concern about foreign public opinion in the initial period of the camps' existence, was not only the previously-mentioned book entitled Konzentrationslager Oranienburg by Schäfer, but also the relatively frequent permits to visit the camps. Of course, they were mostly staged. Before selected journalists (often sympathisers of the regime) or delegations (e.g. representatives of the International Red Cross) were allowed to enter the area of the model lager (Musterlager), it was restored to order, the hospital was restocked, the internees received clean clothing, better meals, and most of all they were ordered to make the best impression on the visitors. Those were shown only the specially prepared parts of the camp. The guards brought forward prominent internees who looked well, thus limiting the risk of revealing the truth about the lager. Nonetheless, the internees were sometimes able to reveal the actual state of things, e.g. when a visitor asked an internee a question in a language other than German ${ }^{47}$.

That meticulous approach of the Nazi regime to their own image was the foundation of Polish lager literature. Probably the first Polish text on a lager was a series of reports by Jerzy Rogowicz on the concentration camp in Dachau printed between 17 September and 22 November 1936 in Kurier Warszawski ${ }^{48}$. Zbigniew Anculewicz claimed that Rogowicz was the first Polish journalist who was allowed to see with his own eyes what concentration camps truly were ${ }^{49}$. The editor-in-chief

${ }^{44}$ S. Malewski, Karol Ossietzky, laureat nagrody pokojowej Nobla. Nowa Książka, Lviv 1936; K. Rulewicz [aka Weintraub], Karol Ossietzky. Księgarnia Lwowska, Lviv 1937 [aka 1936].

${ }^{45}$ Vide "O wolność dla pacyfistów niemieckich." Robotnik, 1934, issue 231, p. 3.

${ }^{46}$ A. Słonimski, "Kronika tygodniowa." Wiadomości Literackie, 1934, issue 37, p. 6. The outstanding columnist also referred to the persecutions of writers in the Soviet Union about who, as he concluded sarcastically, the western Marxist writers and journalists fighting for Ossietzky failed to remember.

${ }^{47}$ Such a situation was described by Bredel in Examination. Vide also a remark by Oskar Steibler, a former internee, about the visit of an English journalist in Buchenwald in April 1939 included in a report by S. Nogaj, Za drutami i kratami Trzeciej Rzeszy. Reportaże. Vol. 2. Katowice 1939, publ. Stanisław Szarłata, p. 87. On similar visits (including an interview with Ossietzky held in Sonnenburg), vide also P. Mnichowski, Obóz koncentracyjny i więzienie w Sonnenbergu..., pp. 38-40.

${ }^{48}$ J. Rogowicz, "W obozie koncentracyjnym." Kurier Warszawski, 1936, issue 255 (evening issue), pp. 2-3; “Za co? Od jak dawna?”, issue 256 (evening issue), pp. 2-3; “"Wychowanie» przez obóz”, issue 258, p. 6; "Wszerz i wzdłuż obozu”, issue 260 (evening issue), pp. 2-3; “«Korytarz» polski w obozie", issue 308 (evening issue), p. 2; "Jak ich żywią?”, issue 314, p. 5; "Przyszłość obozu", issue 321 , pp. 7-8.

${ }^{49}$ Z. Anculewicz, "Obóz koncentracyjny w Dachau w reportażu Jerzego Rogowicza." Mragowskie Studia Humanistyczne, vol. 2 (2000), p. 13. 
of a Warsaw-based daily without a party affiliation leaning towards National Democracy procured a pass issued by the board of the Bavarian political police in Munich (he had viewed the camp from the outside a few months earlier). As he stressed in his report, he went to KL Dachau, the name of which "became a global epitome of the whole misery of human degradation", with an internalised reluctance: "I knew that in the concentration camp I will [...] not only see the misery of those defenceless people but I will observe it - as if inserting a cool probe into their burning wounds." He also stated that the visit to the camp was not only a "journalistic attraction": for him it was mostly his duty as a journalist ${ }^{50}$. The visitors were guided around the camp by polite officers (and even the warden) nicknamed Virgils ${ }^{51}$, who constantly stressed the educational function of the camp. Rogowicz knew he was participating in a mockery. He talked to the internees, naturally in the presence of the SS officers. The internees said such things and in such a way as not to draw any harm on themselves ${ }^{52}$. When talking to the internees, the warden addressed them as "Sir". Food in the camp proved not that bad. Dachau seemed to the reporter as a camp where people were isolated and educated through labour. It was, of course, inhumane just as it is inhumane to inter people without a sentence. It seems that the main problem the author, a doctor of law $^{53}$, was focussed on was exactly that: whether the internees were imprisoned upon receiving a sentence or not. Rogowicz did, in fact, show his ironic approach condemning the creators of the camp and the guards, he was appalled at times, as a sensitive person should be, however, one would find it hard to identify in his story any borderline terror so common in later reports written during and after WWII. For him, the appearance of the internees was the most inhumane thing: "a welter of grey beings indiscernible from a distance. They are so identical that they do not seem human." ${ }^{54}$ Upon leaving the camp, the author had the impression, included in the final paragraph of his report, that he had woken up "from the strangest dream. That all that did not exist. [...] That all that - is just impossible" ${ }^{\prime 5}$. And that was it, no adamant condemnation, urging,

\footnotetext{
${ }^{50}$ J. Rogowicz, "W obozie koncentracyjnym", p. 2.

${ }^{51}$ J. Rogowicz, "Przyszłość obozu", p. 7. The text included another theme from Dante: the words "lasciate ogni speranza" ("W obozie koncentracyjnym", p. 3).

${ }^{52}$ Before that, in unofficial camps, it was even difficult to manage a pretended interview. Cf. "A few correspondents were allowed to visit the Heudeberg, Dachau and Oranienburg «model camps». The SA accompanied the journalists throughout the camps which were «arranged» especially for the visitors. The journalists could not establish any contact with the internees, not even ask a few questions, without being noticed by their chaperones. Therefore, the reports of foreign journalists were more of impressions on the landscape, the picturesque nature of the concentration camps' surroundings than observation of the state of things" (Brunatna ksiega ..., pp. 253-254).

${ }^{53}$ Vide W. Szyszkowski, "Rogowicz Jerzy”, [in:] Polski stownik biograficzny. Vol. 31. Ossolineum, Wrocław 1988-1989, p. 438.

${ }^{54}$ J. Rogowicz, "W obozie koncentracyjnym", p. 3.

${ }^{55}$ J. Rogowicz: "Przyszłość obozu", p. 8.
} 
open protest. In Rogowicz's report, the camp in Dachau seemed basically not very different from the confinement centre in Bereza Kartuska.

It is worth mentioning that in Gazeta Polska, an established body of the ruling party, Prof. Leon Kozłowski, the Prime Minister and the minister of foreign affairs, using a discourse similar to that of Rogowicz's interviewees, i.e. the Dachau "educators", recalling the resolution which established in Poland the isolation camps, went on to recite the German-sounding phrase "Porządek musi być" (Order must be), and finally concluded emphatically: "Concentration camps. Yes. Why? Because it is obvious that those eight years of work for the greatness of Poland [...] were not enough for some." ${ }^{56}$

The lack of focus on exposing facts in Rogowicz's report or any documented reaction to the text may have resulted from the fact that Poland and Germany were bound by the non-aggression pact, which, NB, the author of the report discussed in Dachau with Heinrich Jasper, a social democratic politician. The pact, concluded on 26 January 1934, was supplemented with a "moral disarmament" agreement, which was to mutually limit anti-German and anti-Polish propaganda in the press, radio, cinema and theatre. The formation of the image of our neighbour was also influenced by the political tendencies of specific periodicals and their

56 "Miejsca odosobnienia. Oświadczenie premjera L. Kozłowskiego.” Gazeta Polska, 1934, issue 168 , p. 2. I shall not settle the relation between Bereza and German concentration camps. I notice the differences separating both institutions, e.g. the number of their respective victims. However, it seems important to refer in the context of Rogowicz's "legally" oriented report to a fragment of the resolution of the President of the Polish Republic of 17 June 1934, which served as the basis for establishing the confinement centre in Bereza Kartuska: "Persons the activities or actions of whom offer the basis for assuming that they might violate the public safety or order, can be subject to detention and enforced relocation to a confinement centre, which is not intended for persons sentenced or arrested in relation to committing crimes" ("Resolution on persons endangering public safety or order." Gazeta Polska, 1934, issue 168, p. 1). I will also add that the first internees sent to Bereza were the representatives of the National Radical Camp (ONR) and members of the Organisation of Ukrainian Nationalists (OUN) but soon the majority of the internees were communists. In 1937, many convicted criminals and some financial criminals were sent there as well. Instead of their names, internees had numbers sewn onto their shirts. They were subjected to both physical and mental abuse. They were forbidden from talking loudly. They were not allowed to receive food packages, and their ability to send letters (censored, written per a template: "I am well and healthy") was limited. No visits were allowed. Their accommodation was below any civilised norms, and food rations were extremely small. Some internees performed hard physical labour, while those who were not working were forced to do exhaustive physical exercises. Within the camp, the internees had to run. They were verbally abused. They were often beaten by policemen as well as their fellow internees - regular criminals. Within the five years of the operations of the camp in Bereza, a dozen or so people died, most of them in the hospital in Kobryń where internees were sent when in serious condition. The command of the confinement centre did everything they could to prevent the internees from dying within its area (vide I. Polit, Miejsce odosobnienia w Berezie Kartuskiej w latach 1934-1939. Adam Marszałek, Toruń 2003; W. Śleszyński, Obóz odosobnienia w Berezie Kartuskiej 1934-1939. Benkowski, Białystok 2003). 
journalists ${ }^{57}$. More explicit texts regarding the misdeeds of the Nazi regime began to appear soon after Hitler unilaterally renounced on 28 April 1939 the abovementioned pact and Germany started a full-on anti-Polish propaganda campaign. Two important texts regarding the German camps were published in the press right before the outbreak of WWII.

The more extensive of the two with more comprehensive content was the memoir presented in Gtos Lubelski, an organ of National Democracy, entitled Bytem w piekle... by Władysław Wójcik of his several-month-long interment in Buchenwald $^{58}$. It fulfilled two main goals: to inform and to caution. Both were indicated in the words of an internee, an emaciated Jew directed to the author: "once you're free, don't forget to voice what you have seen here, it is your sacred duty, that way you may be able to save thousands from terrible death." Wójcik mentioned that he was arrested on 29 October 1938 while travelling from Belgium to Poland for a minor infringement of border traffic laws. Upon being held for five weeks in a prison in Aachen, he was officially sentenced to one day in jail, yet he was sent to Buchenwald. He remained there until the summer of 1939. Apart from a few fragments which constituted an ecstatic expression of patriotism, Wójcik's recollections constituted an exceptionally factual presentation of the camp. One could even consider them a report considering the fact that the author stated little about his own stay in the lager. He rather revealed his emotions towards that which he saw. Most of all, though, he was an extremely careful observer ("I observed with interest") and a witness. His text included detailed information regarding the location of the camp, how the internees were treated (tormented and murdered), their nutrition, labour, and escapes. He also provided the names of the camp's command and some of his fellow internees who served the oppressors. His observations, recorded meticulously and often expressed in the form of a visualising description, constituted an argument aimed at persuading the reader about the true nature of Germans and their intentions towards Poland. The concentration camp was "a hellish ordeal of man's eternal soul", but most of all, from the perspective of Wójcik, a Polish patriot, "cruel captivity [created by] our mortal enemies", the

${ }^{57} \mathrm{Cf}$. " $[. .$.$] it is interesting that, e.g. English periodicals, mainly the conservative «Times»$ magazine, provide much more detail of German atrocities and much more frequently than the Polish press. [...] I justify that before myself by the fact that the main sources of information on today's Germany for the Polish press are the correspondents of Polish state or semi-state agencies or of Polish periodicals directly or indirectly dependent on the government. [...] the calmness of Polish opinion has become the strongest asset in the difficult game the Polish ministry of foreign affairs faces" (A. Sobański, Cywil w Berlinie. Rój, Warsaw 1934, pp. 70-71). Sobański in an extremely interesting report provided information on, e.g. crowds of people "concentrated in Sonnenburg, Oranienburg, and many other camps and prisons" (ibid., p. 68).

${ }^{58} \mathrm{~W}$. Wójcik, "Byłem w piekle... Lublinianin w niemieckim obozie koncentracyjnym w Buchenwaldzie." Gtos Lubelski, 1939, issue 225, p. 5; issue 226, p. 5; issue 227, p. 7; issue 229, p. 5 ; issue 230 , p. 6 ; issue 231 , p. 5 ; issue 232 , p. 5; issue 233, p. 5; issue 234, p. 6; issue 236, p. 5; issue 237 , p. 5 ; issue 238 , p. 5 ; issue 239 , p. 5 . 
essence of Germanness. His stay at the camp was, for the author (and was to be for the reader), a lesson: "I have learnt the naked truth about who they are... And I am now sure that we will be safe only when we crush the heads of the insolent and greedy Germans!..." "Soon may be the hour of revenge against the pride and insolence of Poland's eternal enemy." Unfortunately, the remark of an SS officer directed at the author just before he was released from the camp proved just as truthful: "You have no reason to go to Poland; soon, you will be interned again as a POW." The final part, which included those words, was published in the newspaper issued on 1 September.

Another important text which was published in the press in 1939 was a report with photographs entitled "W niemieckich obozach koncentracyjnych" published anonymously on 2 July in the Poznan-based Przewodnik Katolicki, one of the most popular Polish socio-religious periodicals ${ }^{59}$. It was created as a result of its author's visit to Germany, based on interviews with several former, as it was originally stated, camp "guests". It was a not too extensive, clearly factual text aimed at providing information, presenting to the reader what "in general, a German concentration camp looked like and the mode of its forced inhabitants." The author avoided exaltation, rather attempting in consecutive short chapters to describe the phenomenon and understand it: the location and the appearance of the camps, the way of living and the differences between the internees, their assignment to the camps and maintaining discipline, labour and attempts at escape, and sleeping conditions. Such expressions as: "as I was told" or "apparently" expressed not as much scepticism or doubt as the author's lack of absolute certainty ${ }^{60}$. The author revealed his moral position discreetly. He did not openly condemn the system, but he sympathised with the internees and called them "unfortunate souls." Only once, when he mentioned the suicides committed by the internees, did he give in to emotion, almost a preaching passion: "that is done only by those for whom in those terrible circumstances the light of faith does not shine, who do not expect anything past this existence having lost for whatever reason their childhood creed." It is also worth quoting the first sentence of the, compared to the post-WWII camp literature, nearly emotionless report: "We know Soviet concentration camps

59 "W niemieckich obozach koncentracyjnych." Przewodnik Katolicki, 1939, issue 27, pp. $439-440$.

${ }^{60}$ Similar sentiment was presented by Krzysztof Poraj in a journalistic book published in 1939 entitled Koszary i koszmary: "topical literature, which now consists of dozens of volumes and includes reports and descriptions which are sometimes blood-curdling, does not ensure $100 \%$ certainty. It is impossible to state which pieces of information apply to the core of the matter while others belong to the so-called Greuelpropaganda" (ibid.: Koszary i koszmary. Księgarnia Polska Bernard Połoniecki, Lviv [1939], p. 132). Poraj did not doubt, however, that terror was in Germany "practised extensively" (ibid., p. 133) and that in the camps internees were treated cruelly. He was outraged by the internment of pastor Martin Niemöller (like Ossietzky, yet another well-known person whose release was demanded by global public opinion before the outbreak of WWII). 
quite well from their various descriptions. German concentration camps are less known to us and the only difference between them and their Soviet counterparts is that they are not located in the Siberian wilderness or polar regions but in the centre of Europe, near Berlin and Munich." Indeed, publications regarding Soviet camps had been published in Poland earlier (as Gulags were established before lagers). In 1930, Mieczysław Lenardowicz published a report entitled "Na wyspach tortur i śmierci" ${ }^{\prime \prime}$.

It is important to stress the fact of "equating" both types of camps, something unthinkable for the majority of contemporary western authors who often sympathised with communism, and displayed pro-Soviet or leftist attitudes. For Poles, who knew well what katorga was and some already knew from their experience what Gulag was ${ }^{62}$, such an alignment was not hard. It took another fifty years for official publications published in Poland to include that type of equalisation once more. But as early as 1937, Stanisław Nogaj published in book form a nearly 100-page-long collection of reports entitled Za kratami i drutami Trzeciej Rzeszy. Two years later, it was renewed. In the same year, the second volume was published, similar in terms of its length but with a different title: $Z a$ drutami i kratami Trzeciej Rzeszy, in 45,000 or 50,000 copies! $!^{63}$ Though, both collections focussed on the internees and German concentration camps, the very first paragraph of the second collection featured a symptomatic analogy: "In the Third Reich, all opponents of the Nazi regime are being fought, just like in Soviet Russia. The difference is that Stalinist-communists murder their opponents openly, maintaining the pretences of legality, arranging some trials, while the Nazis deal with their opponents quietly murdering them covertly without the court mockery" (II, p. 3).

Before WWII, Nogaj was editor-in-chief of the Katowice-based Polonia (from the beginning of the periodical, i.e. 1924), a press body of Christian Democracy, and the popular Siedem Groszy also associated with the party (the 2nd volume, Za drutami i kratami Trzeciej Rzeszy, was published as a free supplement).

${ }^{61}$ M. Lenardowicz, Na wyspach tortur i śmierci. Pamiętnik z Solówek. Wojskowy Instytut Naukowo-Wydawniczy, Warsaw 1930. Cf.: "[...] Polish lager literature probably began at the turn of the 1930s" (E. Czaplejewicz, Polska literatura tagrowa. PWN, Warsaw 1992, p. 40). Czaplejewicz also listed a two-volume collection Za kratami więzień i drutami obozów. Wspomnienia i notatki więźniów ideowych z lat 1914-1921 published in 1927-1928.

${ }^{62}$ Mieczysław Lenardowicz called his three-year internment in the concentration camp on the Solovetsky Islands as katorga, "Soviet katorga" (ibid.: Za czerwonym kordonem. Wspomnienia pobytu w Rosji Sowieckiej. Wojskowy Instytut Naukowo-Wydawniczy, Warsaw 1931, p. 1).

${ }^{63}$ S. Nogaj, Za kratami i drutami Trzeciej Rzeszy. Reportaże. [Polonia], [Katowice] 1937; Za kratami i drutami Trzeciej Rzeszy. Reportaże. [2nd edition. Vol. 1.] [Polonia], [Katowice] 1939; Za drutami i kratami Trzeciej Rzeszy. Reportaże. Vol. 2. Katowice 1939, publ. Stanisław Szarłata (number of copies stated on the cover). I include quotations directly in the text, as per 1939 editions, I mark appropriate volumes using Roman numerals. 
Nogaj's reports did not possess any significant literary value, their style was not excellent, which was probably due to the author's fidelity to the accounts he used, both Polish and (translated) German. The texts, or rather chapters, constituting both volumes had yet another deficiency: they included many repetitions. Nonetheless, it is worth mentioning that their informative value seems priceless today. In an exceptionally detailed and factual manner, without unnecessary emotion, though not without moral engagement, Nogaj presented, based on what he had learnt, how the Nazi regime functioned in its early stages. The reporter's basic intention was to reveal the violations performed in the Reich and in Poland. Thus, Nogaj was one of the forerunners of Polish lager literature. It is also important that he was one of the first to notice that among those persecuted by the Nazi dictatorship, including lager internees, were also Poles, and not only those who were German citizens, but also people with Polish citizenship. Nogaj offered a (certainly inflated) figure of several thousand Poles interned in concentration camps. Most of them were sent there upon being sentenced for alleged espionage (representatives of other nationalities also fell victim to the spy "hysteria" soon after the Nazis' rise to power). According to Nogaj, Poles

\footnotetext{
were sent on purpose to the camps in Lichtenburg and Sonnenburg. After a several-month-long internment in the camps, through the intervention of the Union of Poles in Germany, the Poles were released. Before that they were all forced to sign declarations stating that they will not speak a word on what they experienced in the camps. They have to remain silent or else they or their loved ones will be arrested.

However, we were able to find a few former internees of concentration camps who have nothing to lose and regardless of the obligation they were forced to sign they told us their stories (I, p. 50).
}

Some of them ended up in Poland as a result of an exchange of Polish and German prisoners made on 23 April 1936.

The following chapters of the 1st volume: "Powstaniec śląski Józef Roszak", "Sprawa Paskudy", "Historia Maksymiliana Mitznera", "Obóz w Lichtenburgu", "W obozie Esterwegen-Papenburg," included similar, as if carbon copied stories. Their protagonists mainly included Silesians, patriots, plebiscite activists, and social activists, but also people completely unengaged in any political or social initiatives. Everyone, as it turned out, had been falsely accused of espionage for Poland, sentenced in mock trials, placed in prisons or camps, harassed, and eventually, fortunately, released. Some reached Poland illegally. Nogaj, an obvious patriot, did not only focus on Poles. He also noticed the suffering of Germans: not only communists, social democrats, and those completely apolitical, but also homosexuals, to whom he devoted an extensive passage. He also wrote about the exploitation of internees as cheap labour by private companies and remarked that some of them were sterilised. However, the author never fumed, he never scolded 
anyone. Instead, he offered as precise data as possible ${ }^{64}$ - not only the names of internees and their current addresses (amplifying the reliability of the events upon which he reported), but most of all the names of the dishonest judges and lawyers, the brutal officers, and the prison and camp torturers (he did notice as well some good Germans, also among the lawyers or even among lager guards). Accusation was also present in the precise description of the living conditions of the internees, including forced labour, abuse, and killings in the camps.

The 2nd volume of the reports continued and supplemented the image drawn based on new details acquired by the inquisitive journalist. Its opening chapter entitled "Kobiety w więzieniu" was a rather chaotic description, or rather a series of pieces of information, sometimes anecdotes, regarding the "severe prison" (Zuchthaus) in Jauer (Jawor) in Silesia, using details acquired from Maria Voreiter, a former prisoner. The chapter entitled "Przygody bezrobotnego z Nowej Wsi" was based on an account of a Polish labourer released from a concentration camp. The memories of Franciszek J. (he did not want to lose the high pension he was awarded by the court), falsely interned in Buchenwald, indicated that in 1938 the camp also included Polish internees. The "informers" in that chapter also included former prisoners, refugees from Germany, temporarily located in Katowice, and among them an "Upper Silesian from Gliwice," a Polish emigrant who was a social democratic activist in Germany later interned at Lichtenburg and Buchenwald. Nogaj quoted in extenso a rather long report on the "adventures" of that internee submitted to the Committee of Political Émigrés in Katowice. (It seems that the direct and the most common source of Nogaj's stories in the 2nd volume were those reports submitted to the Committee). However, the motivation behind the inclusion of that account is unclear: the journalist gave priority to the information and moral significance of the account - "inform the entire cultural world of the barbaric methods of the Nazis" (II, p. 51) - over the safety of the witness who was afraid of the Gestapo taking revenge on him as they operated outside the Reich as well (the painful results of truthfulness, a fact which Nogaj experienced himself soon afterwards). The third chapter entitled "Tragedia pewnego sekretarza niemieckiej partii chrześcijańsko-socjalnej i jego przygody w obozach i więzieniach hitlerowskich" was an account submitted to the Committee by a political émigré, a German, held for several years in concentration camps near Elberfeld and Krefeld. Chapter four entitled "Trzeci więzień z Buchenwald i to, co on widział w obozie koncentracyjnym" was written based on a letter by a former Buchenwald internee submitted to "our office" (i.e. the office of the Polonia daily), where he authenticated the descriptions of former internees at the Buchenwald concentration camp (submitted to the office of Polonia? to the Committee?) and offered some clarifications of previously stated facts. Chapter five entitled "Tragedia

${ }^{64}$ Sometimes he made mistakes, e.g. he stated the name of the Esterwegen camp as Ernest-Wesen. 
Żydów w Buchenwald" was one of the first texts in Polish literature on the extermination of the Jews, or rather its onset. Chapter six "Jeszcze jeden więzień z Buchenwald. Co śpiewają w obozach koncentracyjnych?" was a record of the author's interviews with Oskar Steibler, a German internee at Buchenwald, who, after stating that he read newspaper clippings regarding Buchenwald, added with irony (his glass eye and false teeth were serious enough): "Well, it wasn't all that bad in Buchenwald!" (II, p. 81). The final chapter entitled "Tajemnica mordów w Niemczech w dniu 30 czerwca 1934 r." revealed the crime known as "the Night of the Long Knives".

Nogaj soon had his chance to learn about the risk associated with publishing texts revealing the crimes committed by the Nazis. On 9 March 1940 he was arrested by the Gestapo based on a denunciation by a former editorial office colleague ${ }^{65}$. He was first interrogated in the Gestapo headquarters, then he was transferred to the prison in Sosnowiec, and on 12 April he was sent to the transitional camp in the former Schön factory in Sosnowiec. There he was tortured during an interrogation. The torturers become even more aggressive upon learning that he was the author of a book "against Germans" entitled Bosogarda and of a work entitled Za drutami i kratami Trzeciej Rzeszy ${ }^{66}$. Indeed, Bosogarda, published in 1935 with the subtitle Opowiadanie historyczne dla młodzieży and describing the struggles of Poznan youth against Germanisation towards the end of the 19th c., was saturated with anti-German and at the same time patriotic content. It is worth mentioning that both Bosogarda and Za drutami i kratami Trzeciej Rzeszy were included in the 1940 list of Polish anti-German, detrimental, and unwelcome publications developed by the occupying forces ${ }^{67}$. The SS officers, deploring the fact that Nogaj will not be able to experience Buchenwald directly, sent him through Dachau to the Gusen concentration camp. Those facts were included in a book entitled Gusen. Pamiętnik dziennikarza published by Nogaj in three parts in the years 1945-1946. However, that was quite a different part of the history of Polish lager literature, preceded by a second stage marked by the publications released during WWII and the occupation ${ }^{68}$.

${ }^{65}$ S. Nogaj, Gusen. Pamiętnik dziennikarza. Part 1. Katowice 1945, Komitet b. więźniów obozu koncentracyjnego Gusen, pp. 5-9.

${ }^{66}$ The memoir entitled Gusen could indicate that Nogaj was also the author of Buchenwald. That book was not, however, recorded in the "Official List of Prints Published in the Republic of Poland" or any other catalogue of the biggest Polish libraries. The author most probably quoted a variant of the title (or rather its strapline) included on the cover of the second volume (Za drutami i kratami Trzeciej Rzeszy), i.e. Jauer - Buchenwald. Ofiary Hitlera.

${ }^{67}$ Liste des deutschfeindlichen, schädlichen und unerwünschten polnischen Schrifttums. Herausgegeben im Amt des Generalgouverneurs für besetzen polnischen Gebiete. Issue 1. Ost, Krakow 1940, p. 25.

${ }^{68}$ Vide A. Morawiec, Literatura $w$ lagrze, lager $w$ literaturze... (ch. "Więc moje pisanie to dopiero początek...”. Polska literatura lagrowa w okresie drugiej wojny światowej). 


\section{Bibliography}

Abraham M., Juda verrecke. Ein Rabbiner im Konzentrationslager. Introduction K. L. Reiner. Teplitz-Schönau 1934.

Als sozialdemokratischer Arbeiter im Konzentrationslager Papenburg. Introduction W. Bredel. Moscow 1935.

Anculewicz Z., “Obóz koncentracyjny w Dachau w reportażu Jerzego Rogowicza.” Mrąowskie Studia Humanistyczne, vol. 2 (2000).

Aus Hitlers Konzentrationslagern. K. Bürger (ed.). Moscow 1934.

Autobiografia Rudolfa Hössa, komendanta obozu oświęcimskiego Trans. W. Grzymski. Foreword F. Ryszka. Notes developed by A. Pankowicz. Warsaw 1990.

Beimler H., Im Mörderlager Dachau. 4 Wochen in den Händen der Braunen Banditen. Moscow 1933.

Beimler H., In hitleristishn kontsentracye-lager Dakhau. For vokhn in di hent fun di broyne banditn. Trans. V. L. Z. Varshe 1934.

Beimler H., W katowni faszystowskich zbirów. Foreword G. Rwala. Moscow 1934.

Billinger K. [aka Massing P. W.], Schutzhäftling 880. Aus einem deutschen Konzentrationslager. Roman. Paris 1935.

[Borowski T.], “Czasy pogardy”, [in:] [ibid.], gdziekolwiek ziemia... cykl poetycki. [Warsaw 1942].

Braunbuch über Reichstagbrand und Hitler Terror. Basel 1933.

Bredel W., Egzamin. Powieść. Trans. A. Linke. Warsaw 1954.

Bredel W., Die Prüfung. Roman aus einem Konzentrationslager. London 1934.

Brunatna ksiega. Podpalenie Reichstagu i teror [!] hitlerowski. Foreword Lord Marley. Warsaw 1934.

Cieślak T., Oranienburg-Sachsenhausen. Hitlerowskie obozy koncentracyjne 1933-1945. Warsaw 1972.

Czaplejewicz E., Polska literatura łagrowa. Warsaw 1992.

Deutsch für Deutsche. Leipzig [1935].

Dunin-Wąsowicz K., Ruch oporu w hitlerowskich obozach koncentracyjnych 1933-1945. 2nd edition. Warsaw 1983.

Dymek S., Hans Beimler (1895-1936). Warsaw 1975.

Escaped Prisoner, The Sonnenburg Torture Camp. New York 1934.

Fiedor K., Militaryzmowi i faszyzmowi-nie. Carl von Ossietzky, życie i walka. Warsaw 1986.

Frank B., Der Reisepass. Roman. Amsterdam 1937.

Frank B., Paszport księcia. Trans. R. Granicy. [Lviv 1938].

Das Gesetz zur Ordnung der Nationalen Arbeit. Leipzig [1934].

Gittig H., Illegale antifaschistische Tarnschriften 1933 bis 1945. Leipzig 1972.

Gul R. B., Oranenburg. Čto ja videl v gitlerovskom koncentrationnom lagere. [Paris 1937].

Hinrichs K., Staatliches Konzentrationslager VII. Eine „Erzihungsanstalt” im Dritten Reich. London 1936.

Hirsch W., Hinter Stacheldraht und Glitter. Erlebnisse und Erfahrungen in den Konzentrationslagern und Gafängnissen Hitlerdeutschlands. Zürich-Paris 1934.

Hirsch W., Sozialdemokratische and kommunistische Arbeiter im Konzentrationslager. [Strasbourg] 1934.

Hornung W. [aka Zerfa $\beta$ J.], Dachau - Eine Chronik. Zürich 1936.

Kachnicz Z., "Muzyka, pieśni i piosenki jako sposób na samoobronę psychiczną więźniów obozów hitlerowskich." Przegląd Humanistyczny, 2005, issue 2.

Kiedrzyńska W., "Międzynarodowa bibliografia hitlerowskich obozów koncentracyjnych 19331976." Biuletyn Głównej Komisji Badania Zbrodni Hitlerowskich, [vol.] 30 (1981).

Kiedrzyńska W., Ravensbrück. Kobiecy obóz koncentracyjny. 2nd edition, amended. Warsaw 1965. 
Kogon E., Der SS-Staat. Das System der deutschen Konzentrationslager. Frankfurt am Main 1946. Kühnrich H., Der KZ-Staat. Die faschistischen Konzentrationslager 1939 bis 1945. Berlin 1980.

Kulesza D., Dwie prawdy. Zofia Kossak i Tadeusz Borowski wobec obrazu wojny w polskiej prozie lat 1944-1948. Białystok 2006.

Kunicki W., "Liepmann Heinz”, [in:] Pisarze niemieckojęzyczni XX wieku. Leksykon encyklopedyczny PWN. Marek Zubyra (ed.) Warsaw 1996.

Langhoff W., Die Moorsoldaten. 13 Monate Konzentrationslager. Unpolitischer Tatsachenbericht. Zürich 1935.

Lenardowicz M., Na wyspach tortur i śmierci. Pamiętnik z Sołówek. Warsaw 1930.

Lenardowicz M., Za czerwonym kordonem. Wspomnienia pobytu w Rosji Sowieckiej. Warsaw 1931.

[Liepmann H.], "Śmierć made in Germany". Wiadomości Literackie, 1934, issue 1.

Liepmann H., Das Vaterland. Ein tatsachen Roman aus dem heutigen Deutschland. Amsterdam 1933.

Liepmann H., Śmierć made in Germany. Powieść. Trans. I. Berman. Lviv [1934].

Liste des deutschfeindlichen, schädlichen und unerwünschten polnischen Schrifttums. Herausgegeben im Amt des Generalgouverneurs für besetzen polnischen Gebiete. Issue 1. Krakow 1940.

Makowiecki A. Z., "Opowieść o zagładzie: Seweryny Szmaglewskiej «Dymy nad Birkenau».” Kultura, 1969, issue 26.

Malewski S., Karol Ossietzky, laureat nagrody pokojowej Nobla. Lviv 1936.

Malraux A., Czasy pogardy. Trans. W. Rogowicz. Warsaw 1936.

Malraux A., Le temps de mépris. Paris [1935].

Mańkowski Z., "Obozy hitlerowskie - Majdanek - Lubelszczyzna”, [in:] Majdanek 1941-1944. T. Mencel (ed.) Lublin 1991.

Meyer W., Wernicke K., Der Elektromotor im Kleingewerbe und Haushalt. Leipzig [1934].

"Miejsca odosobnienia. Oświadczenie premjera L. Kozłowskiego." Gazeta Polska, 1934, issue 168.

Mnichowski P., Obóz koncentracyjny i więzienie w Sonnenburgu (Stońsku) 1933-1945. Warsaw 1982.

Morawiec A., Literatura w lagrze, lager w literaturze. Fakt-temat-metafora. Wydawnictwo Akademii Humanistyczno-Ekonomicznej w Łodzi, Łódź 2009.

Mord im Lager Hohenstein. Berichte aus dem Dritten Reich. Moscow 1933.

Musioł T., Dachau 1933-1945. 2nd edition, amended. Opole-Katowice 1971.

Niedyskrecje pocztowe. Korespondencja Tadeusza Borowskiego. Collected, explained, and discussed by Tadeusz Drewnowski. Warsaw 2001.

Nogaj S., Gusen. Pamiętnik dziennikarza. Part 1. Katowice 1945.

Nogaj S., Za drutami i kratami Trzeciej Rzeszy. Reportaże. Vol. 2. Katowice 1939.

Nogaj S., Za kratami i drutami Trzeciej Rzeszy. Reportazee. [Katowice] 1937.

Nogaj S., Za kratami i drutami Trzeciej Rzeszy. Reportaże. [2nd edition. Vol. 1. Katowice] 1939.

Obóz w Dachau. Trans. Z. Gr[abowski]. Wiadomości Literackie, 1937, issue 51.

"O czym p. Goebbels nie mówił w Warszawie? Obóz izolacyjny - Oranienburg”. Robotnik, 1934, issue 221.

"Oświęcimskie książki." Wolni Ludzie, 1947, issue 5.

"O wolność dla pacyfistów niemieckich." Robotnik, 1934, issue 231.

Pilichowski Cz., "Hitlerowskie obozy i ośrodki przymusowego odosobnienia oraz ich rola w realizacji programu ludobójstwa i zagłady narodu polskiego", [in:] Obozy hitlerowskie na ziemiach polskich 1939-1945. Informator encyklopedyczny. Author and editorial team: Czesław Pilichowski et al. Warsaw 1979.

Polit I., Miejsce odosobnienia w Berezie Kartuskiej w latach 1934-1939. Torun 2003.

Poraj K., Koszary i koszmary. Lviv [1939].

Rajewski L., "Seweryna Szmaglewska.” Na straży, 1963, issue 23. 
Rogowicz J., "W obozie koncentracyjnym.” Kurier Warszawski, 1936, issue 255 (evening issue); "Za co? Od jak dawna?”, issue 256 (evening issue); “"Wychowanie» przez obóz”, issue 258; "Wszerz i wzdłuż obozu”, issue 260 (evening issue); "«Korytarz» polski w obozie”, issue 308 (evening issue); "Jak ich żywią?", issue 314; "Przyszłość obozu”, issue 321.

Rost N., De brouwerij van Oraniënburg. Een concentratiecamp in het Derde Rijk. Amsterdam 1933.

"Rozporządzenie w sprawie osób zagrażających bezpieczeństwu, spokojowi i porządkowi publicznemu." Gazeta Polska, 1934, issue 168.

Rulewicz [aka Weintraub] K., Karol Ossietzky. Lviv 1937 [correctly 1936].

Ryszka F., Państwo stanu wyjątkowego. Rzecz o systemie państwa i prawa Trzeciej Rzeszy. 3rd edition, amended. Wrocław 1985.

Schäfer W., Konzentrationslager Oranienburg. Das Anti-Braunbuch über das erste deutsche Konzentrationslager. Berlin [1934].

Seger G., Oranienburg. Erster autentischer Bericht eines aus dem Konzentrationslager Geflüchteten. Afterword by H. Mann. Karlsbad 1934.

Siegelberg M., Schutzhaftjude 13877. Die Leidensgeschichte zweier Menschen. Shanghai 1939.

Skwarczyńska S., Wstęp do nauki o literaturze. Vol. 1. Warsaw 1954.

Słonimski A., "Kronika tygodniowa." Wiadomości Literackie, 1934, issue 37.

Sobański A., Cywil w Berlinie. Warsaw 1934.

Sofsky W., The Order of Terror. The Concentration Camp. Trans. W. Templer. Princeton 1997.

Szyszkowski W., "Rogowicz Jerzy", [in:] Polski słownik biograficzny. Vol. 31. Wrocław 1988-1989.

Śleszyński W., Obóz odosobnienia w Berezie Kartuskiej 1934-1939. Białystok 2003.

Vogler H., "Liryka i piekło." Gazeta Polska, 1946, issue 69.

Werner A., "Wstęp", [in:] Borowski T., Utwory wybrane. A. Werner (ed.) Wrocław 1991.

"W niemieckich obozach koncentracyjnych." Przewodnik Katolicki, 1939, issue 27.

Wójcik W., "Byłem w piekle... Lublinianin w niemieckim obozie koncentracyjnym w Buchenwaldzie." Glos Lubelski, 1939, issues 225-227; 229-234; 236-239.

Wyka K., "Pogranicze powieści." Twórczość, 1946, vol. 2.

"Z praktyki obozów izolacyjnych. Los Karola Ossietzkyego.” Robotnik, 1934, issue 237.

Zürcher F., Kreuzzug gegen das Christentum. Zürich-New York 1938.

Zürcher F., Krucjata przeciw chrześcijaństwu. Zurich-New York 1938.

\section{Polish literature and the Konzentrationslager}

(Summary)

In the article the author discusses the beginnings of Polish camp literature, more precisely: literature referring to the Nazi German concentration camps. For decades it was assumed that the earliest Polish texts of that type were published in 1945. It appears that the first works - reports and memoirs - were published before the outbreak of WWII. In this article, the author discusses them in the historical and historical-literary contexts (mainly in the context of German writings).

Key words: Concentration camp literature; definition; concentration camp 